\title{
TO IMPROVE STUDENTS' INTERPERSONAL COMMUNICATION SKILLS BY MEANS OF COOPERATIVE LEARNING IOC AT PIBA PROGRAM OF UIN ALAUDDIN MAKASSAR
}

\author{
Syarif Hidayat $\mathbf{N}$ \\ Education Faculty UIN Alauddin Makassar \\ syarifnasin@yahoo.co.id
}

\begin{abstract}
This study was a CAR situated at the second semester students of Foreign Language Intensive Program (PIBA) of UIN Alauddin Makassar. The students experienced crusial problems in Interpersonal Conversation. They seemed likely afraid to talk as well as to speak something in front of the class. Moreover, they considered spoken English such a hell subject. Consequently, the study employed a kind of Cooperative Learning named Inside Outside Circle in the learning process to introduce better English conversation to students. Finally, it was found that there was a significant achievement as well as a marvelous performance gained by students from the first up to the second cycle. The mean score at pre cycle test was only 15, 45 . Then, It raised up to 46,80 at the first cycle as well as 70,20 at the second cycle. Furthermore, the highest score of pre-test was 37 and changed to 80,71 in the first cycle post test, then raised up to $\mathbf{8 9 , 1 2}$ in the second cycle. Otherwise, the lowest score is $\mathbf{1}$ becomes $\mathbf{1 8}$ in the first cycle and $\mathbf{6 0}$ in the second cycle. Thus, the Cooperative Learning model IOC could increase the students' capability of conducting better English Interpersonal Conversation as well as encourage students' class involvement.
\end{abstract}

\section{KEY WORDS:}

\section{A. INTRODUCTION}

eaching spoken English in particular likely seems complicated. As a
matter of case, a large number of teachers occasionally find difficulty
doing such kind of activity. Speaking itself as productive skill has significant role in communication especially in doing interpersonal conversation whether with our mates or other new faces. Within speaking, people can both convey information or ideas and maintain social relationship with others. Rasjid (2008) states that one of aims in teaching English as a second language is to make the learners able to communicate effectively in speaking English. Therefore, many 
language teachers concern on helping students to enhance their students' ability in producing English orally in particular their students' interpersonal speaking competence in order to make them speak and share well to the listeners.

Unfortunately by the time the researcher taught and observed English learning activity in the class of PIBA program of UIN Alauddin Makassar, a couple of students' problems in speaking already appeared. Most of students likely did not have good confidence when they spoke even in front of their classmates. In addition, they had not motivation to speakas well as enough vocabulary. They also spoke ungrammatically and they could not pronounce some words well. Consequently, when I instructed them to stand up in front of their friends to talk something or to share with their classmates they seemed performing for nothing. It looked they are afraid to talk, to speak, and to pronounce their words even they had many ideas on their mind but they were incapable of actualising those ideas through speaking. Unfortunately, they no longer had interest to practice their speaking in front of the class.

The researcher noticed that the causes of that low achievement of students' ability in speaking interpersonally were; both students rarely practiced spoken English with their instructor routinely and the learning-teaching process were less in variation. Moreover, the students looked like lazy to speak something in English. As a matter of case, they were less in practice and more doing nothing useless. They were frightening to practice their English language even either inside or outside the classroom. They were also afraid of making mistakes. Consequently, they were easy to feel down when their friends suddenly laugh because something trouble happened with their speaking such as their error pronounciation.

\section{Statements of the Problem}

I undoubtedly formulated two problem statements, which were: 1) what will happen with students' interpersonal conversation achievement afterutilizing this IOC learning style?2). Can cooperative learning through IOC enhance the students' competence in doing interpersonal conversation?

\section{B. PURPOSES OF THE RESEARCH}

The research objectives of this research aimed at two primary goals covering: 1). To figure out in what extends the ICO benefit students interpersonal conversation competence. 2). To find out whether this IOC learning style is effectively success or not to improvethe students' interpersonal conversation competence at PIB A Program of UIN Alauddin Makassar. 
Syarif H.N., To Improve Students' Interpersonal Communication Skills By Means of Cooperative ...

\section{Research Significances}

The results of this study are hopefully to give more proofs in terms of the cooperative learning generallywhich is excellent to use in English class in order to improve the students' achievement in speaking. Likewise, to acknowledge students and teachers in particular, about the best way to foster students Interpersonal conversation competence at PIBA program of UIN Alauddin Makassar.

\section{Delimitation of The Research}

The researcherfocused on identifying the students' conversation problem, overcoming the students' problem in conducting conversation, and fostering the students' ability in leading interpersonal conversation through cooperative learning based on Inside-Outside circle at PIBA program of UIN Alauddin Makassar.

\section{Research Hypothesis}

It is assumed that the students' competence in conducting interpersonal conversation can be enhanced through implementing cooperative learning model inside-outside circle.

\section{METHODS AND PROCEDURES OF THE RESEARCH}

The researcher applied a classroom action research (CAR), which is considerably as a common way conducted by the instructors or the teachers of making their students comprehend the materials. Kemmis and Taggart (in Wiriaatmadja, 2006:66) described the models and the procedures of Classroom Action Research which later are classified into four steps. They are; (1) plannings, (2) actions, (3) observations, and (4) reflections. The relations among them is therefore namely as a cycle. It means that each cycle consists of planning, acting, observing, and reflecting. Thus, I ran having three cycles of research, as the minimum cycling process in CAR, which consists of planning, action, observation, evaluation and reflection.

\section{LITERATURE REVIEW; THEORY AND CONCEPT}

\section{a. Previous studies}

To begin with, Indah Fadhilah Rahman (2010:53) in her research observed the effectiveness of implementing cooperative learning jigsaw approach toward reading comprehension. She eventually found effectiveness of using cooperative 
learning jigsaw approach to enhance reading comprehension of students. Following this, Rusmiati in Sukirman (2010:2) concluded that the students' attitude towards the application of cooperative learning was interesting, so they are motivated to learn English subject.

According to David and Roger (2010:10), cooperative learning is a successful startegy in which small teams, each with small teams, each with students of different level ability.As the conclusion, those findings above describe that using cooperative learning in conducting English materials can make students learn, achieve, and get the goals easily.

\section{b. Interpersonal Communication}

In addition to basic concepts of this study, in accordance with Houghton Mifflin (2000), interpersonal relationship is communication among people sending and accepting ideas one another. Therefore here are some following tips that can support interpersonal relationship well done. The first, conduct your conversation in a full of grace and Avoid egoism when talking. Secondly, try to conduct your interpersonal relationship in balance way. Thirdly, listen others quickly, speak to others slowly and avoid to be temprament.

\section{c. Cooperative Learning}

According to Johnson (1991), cooperative means working together to accomplish shared goals. Likewise, it is only under certain conditions that cooperative efforts may be expected to be more productive than competitive and individualistic efforts. It includes positive Independence (sink or swim together); face-to-Face Interaction (promoteeach others' success); individual and Group Accountability; interpersonal and Small-Group Skills; Group Processing

\section{d. Inside - Outside Circle}

Inside - Outside Circle is a simple strategy for students to share information when questioning, sharing, or problem solcving in class (Kagan, 2009).During this strategy, students form two different circles: a half of the group stands in a circle facing outwars while the others half forms a circle around them facing inward. Students exchange information untill the teacher signals the outer circle to move in one direction.

According to Eilks and Witteck (2003), this is the figure of IOC method: 


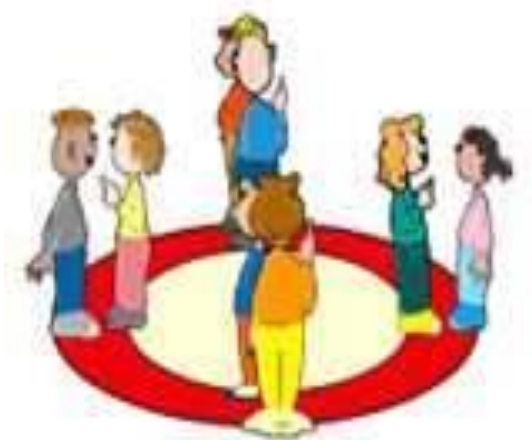

\section{E.FINDING AND DISCUSSION}

It was found that none of students did excellent communication. They likewise were afraid to talk, and likely less confidence to communicate in front of public such the whole classroom. Also, the students rarely pronounce words with their friends in good fluency. Besides that, they were lack of speaking accuracy with losing his ideas while they were speaking at a time. Their speaking comprehension also was under connecting either. They poorly comprehend what their partners talking about and always misunderstanding with class information. Overall, both of students' learning result and their class participation were fair.

\section{Learning Activity Progress}

In terms of students' learning activities in the C1 of the research, I gained some improving activities, which were: (1) the students were doing their conversation based on the teacher's instruction, (2) they gave question to their teacher if they find an unclear instruction, (3) they gave comments and suggestions about their partners' ideas, (4) Moving regularly with their circle based on the teacher's instruction, (5) discussing and working together with their friends in doing their conversation. Whereas, the students' creativity consisted of three indicators; (1) Showing their curiosities with asking question to their teacher and friends,(2) Exploring their ideas as well as sharing their information to other partners, (3) Thinking seriously to their partners' ideas and giving comment excellently.

Furthermore, the students' emotion consisted of one indicator including (1)They involved themselves in the class with high feeling and notgetting sleepy during the class. Additionally, the students' class cooperation consisted of three indicators; (1) the students discussed things with their teachers, (2) the students exchanged things with their partners staying from another circle, and (3) the students 
worked together with their friends accomplishing the goals as seen immediately in the following figure:

Fig 1. The Percentage of Students Class Participation of the First Cycle

\begin{tabular}{|c|c|c|}
\hline $\begin{array}{l}\text { Aspects } \\
\text { Observed }\end{array}$ & Indicators & Percentage $\%$ \\
\hline \multirow{5}{*}{$\begin{array}{l}\text { Learning } \\
\text { Activities }\end{array}$} & $\begin{array}{l}\text { Doing their conversation based on the } \\
\text { teacher's instruction. }\end{array}$ & 70 \\
\hline & $\begin{array}{l}\text { Asking question to their teacher if there is an } \\
\text { unclear instruction }\end{array}$ & 60 \\
\hline & $\begin{array}{l}\text { Giving comments and suggestions about } \\
\text { their friends' ideas (supporting conversation) }\end{array}$ & 45 \\
\hline & $\begin{array}{l}\text { Moving regularly with their circle based on } \\
\text { teacher's instruction. }\end{array}$ & 60 \\
\hline & $\begin{array}{l}\text { Discussing and sharing together with their } \\
\text { friends in doing their conversation }\end{array}$ & 65 \\
\hline \multirow{3}{*}{ Creativity } & $\begin{array}{l}\text { Showing their curiosities with asking } \\
\text { question to their teacher and their partners }\end{array}$ & 40 \\
\hline & $\begin{array}{l}\text { Exploring their ideas as well as sharing their } \\
\text { information to others }\end{array}$ & 50 \\
\hline & $\begin{array}{l}\text { Thinking seriously to their partners' ideas } \\
\text { and giving comment excellently }\end{array}$ & 50 \\
\hline Emotion & $\begin{array}{l}\text { Being active participant in the class with high } \\
\text { involvement and notgetting sleepy during the } \\
\text { class }\end{array}$ & 55 \\
\hline \multirow{4}{*}{ Involvement } & Discussing with their teacher & 55 \\
\hline & Discussing with their partners (circle) & 75 \\
\hline & $\begin{array}{l}\text { Working together with their partners } \\
\text { (answering the quiz, if any) }\end{array}$ & 65 \\
\hline & Mean Score & 58,75 \\
\hline
\end{tabular}

It seemed that the students' participation was not good enough in case It was still under expectation with only $\mathbf{5 8 , 7 5 \%}$ of the participation in the pedagogical process (learning and teaching). Therefore, some indicators which are not achieved above will be forcely enhanced in the next two cycles, including the students' attention having discussion with their teacher, the way the students exploring their ideas into discussion, and the way the students giving comments and suggestion to their friends' ideas. 
Syarif H.N., To Improve Students' Interpersonal Communication Skills By Means of Cooperative ...

Latterly,comparing between the first and the second cycle class observation,it was found that the students' participation in the learning process increased quite better in the second cycle. As a finding, the ways of students involving the class became better. For further detailed data, look at the comparison below:

Fig 2. Comparison of Students' Participation between the First Cycle (C1) and the Second Cycle (C2)

\begin{tabular}{|c|c|c|c|c|}
\hline \multirow{2}{*}{$\begin{array}{l}\text { Aspects } \\
\text { Observed }\end{array}$} & \multirow{2}{*}{ Indicators } & \multicolumn{2}{|c|}{ Score } & \multirow{2}{*}{ Change } \\
\hline & & $\mathrm{C} 1$ & $\mathrm{C} 2$ & \\
\hline \multirow{5}{*}{$\begin{array}{l}\text { Learning } \\
\text { Activities }\end{array}$} & $\begin{array}{l}\text { Doing their conversation based on the } \\
\text { teacher'sinstruction. }\end{array}$ & 70 & 80 & +10 \\
\hline & $\begin{array}{l}\text { Asking question to their teacher if } \\
\text { there is an unclear instruction }\end{array}$ & 60 & 70 & +10 \\
\hline & $\begin{array}{l}\text { Giving comments and suggestions } \\
\text { about their friends' ideas (supporting } \\
\text { conversation) }\end{array}$ & 45 & 70 & +25 \\
\hline & $\begin{array}{l}\text { Moving regularly with their circle } \\
\text { based on teacher's instruction. }\end{array}$ & 60 & 75 & +5 \\
\hline & $\begin{array}{l}\text { Discussing and sharing together with } \\
\text { their friends in doing their } \\
\text { conversation }\end{array}$ & 65 & 65 & 0 \\
\hline \multirow{3}{*}{ Creativity } & $\begin{array}{l}\text { Showing their curiosities with asking } \\
\text { question to their teacher and partners. }\end{array}$ & 65 & 70 & +5 \\
\hline & $\begin{array}{l}\text { Exploring their ideas as well as sharing } \\
\text { their information to others }\end{array}$ & 40 & 65 & +25 \\
\hline & $\begin{array}{l}\text { Thinking seriously to their partners } \\
\text { ideas and giving comment excellently }\end{array}$ & 50 & 70 & +10 \\
\hline Emotion & $\begin{array}{l}\text { Being active participant in the class } \\
\text { with high involvement and notgetting } \\
\text { sleepy during the class }\end{array}$ & 55 & 65 & +10 \\
\hline \multirow[b]{3}{*}{ Involvement } & Discussing with their teacher & 55 & 50 & -5 \\
\hline & Discussing with their partners (circle) & 75 & 85 & +10 \\
\hline & $\begin{array}{l}\text { Working together with their partners } \\
\text { (answering the quiz if available) }\end{array}$ & 65 & 85 & +20 \\
\hline \multicolumn{2}{|l|}{ Mean Score } & 58,75 & 70,83 & $+12,08$ \\
\hline
\end{tabular}

The further figure above reveals the information that there were a number of improvement of students' participation in learning process at the second cycle. It gained higher score of percentage $\mathbf{( 7 0 , 8 3 \% )}$ than the score of the first cycle with only $(\mathbf{5 8 , 7 5 \% )}$. Furthermore, the students' first class observation was only categorized fairly good whereas in the second cycle the observation score achieved good level. That means there was a bit improvement of students' class participation following the conversation in the class with space $\mathbf{1 2 , 0 8}$. That improvementcaused the researcher 
becoming proud even the space was not very significant in case the action process in the second cycle influenced the students to be much more active in participating the class.

\section{Learning Output}

The researcher found few kinds of the students' learning output as long as this research was conducted including their speaking output before and after the class implementation (the first and the second gycle). As the result, he found different outputs of students' learning among the pre-cycle test, the first cycle test, and the second cycle test.

In the pre-cycle meetings, as the researcher mentioned earlier that the researcher mostly took over this research because of finding some problems of students' speaking in the previous meetings before action implementation (pre-cycle meetings) during the first semester at most. This case, the researcher gave the students pre-test in order to know their prior speaking ability before implementing actions. Besides that, He had been observing for all the meetings during the first semester in the hope the researcher could detect and find some students' problems in following speaking class. As the result of both pre-cycle test and observation, the output of students' speaking during the first semester was underfine and beyond the researcher's expectation. This pre-cycle test was held on December $28^{\text {th }}, 2013$ (the first semester class) whereas observation was done as long as the first semester running. This is the following output of students' speaking achievement :

Fig 3. The Students' Score of the Pre-Cycle Test (Pre-Action Test)

\begin{tabular}{|l|l|l|c|c|c|c|c|}
\hline \multirow{2}{*}{ No } & \multirow{2}{*}{ ID Number } & \multicolumn{1}{|c|}{ Names } & \multicolumn{3}{|c|}{ Scores } & Total & \multirow{2}{*}{ Grode } \\
\cline { 3 - 6 } & & & F & A & C & \\
\hline 1 & 60900112029 & Intan Ervi Yunita & 2 & 2 & 2 & 6 & 40 \\
\hline 2 & 60900112030 & Nurul Qalby & 2 & 3 & 2 & 7 & 46,67 \\
\hline 3 & 60900112031 & Zainal Masri & 2 & 2 & 3 & 7 & 46,67 \\
\hline 4 & 60900112032 & Muh. Agus Sulawesi & 4 & 4 & 4 & 12 & 80 \\
\hline 5 & 60900112033 & Ervina Rahman & 1 & 2 & 3 & 6 & 40 \\
\hline 6 & 60900112034 & Anisah Risal & 2 & 2 & 3 & 7 & 46,67 \\
\hline 7 & 60900112035 & Putri Asiyah & 2 & 3 & 3 & 8 & 53,33 \\
\hline 8 & 60900112036 & Muhammad Yusuf & 3 & 2 & 2 & 7 & 46,67 \\
\hline 9 & 60900112037 & Rahmat Amirul Salam & 1 & 2 & 2 & 5 & 33,33 \\
\hline 10 & 60900112038 & Siti Hajar & 2 & 1 & 1 & 4 & 26,67 \\
\hline 11 & 60900112039 & Muh. Jalal Mansur & 3 & 1 & 2 & 6 & 40 \\
\hline
\end{tabular}


Syarif H.N., To Improve Students' Interpersonal Communication Skills By Means of Cooperative ...

\begin{tabular}{|c|l|l|c|c|c|c|c|}
\hline 12 & 60900112040 & Mawaddah Rahmah & 2 & 2 & 3 & 7 & 46,67 \\
\hline 13 & 60900112041 & Muhammad Rizal & 3 & 2 & 2 & 7 & 46,67 \\
\hline 14 & 60900112042 & Husnul Hatima & 0 & 0 & 0 & 0 & 0 \\
\hline 15 & 60900112043 & Muniarto & 2 & 2 & 2 & 6 & 40 \\
\hline 16 & 60900112044 & Muh. Nuriman H & 2 & 2 & 2 & 6 & 40 \\
\hline 17 & 60900112045 & Andi Najmatullail & 1 & 1 & 2 & 4 & 26,67 \\
\hline 18 & 60900112046 & Dirman & 3 & 3 & 4 & 10 & 66,67 \\
\hline 19 & 60900112047 & Dewi Ratnasari & 1 & 2 & 2 & 5 & 33,33 \\
\hline 20 & 60900112048 & Muh. Akbar Assiddiq & 0 & 0 & 0 & 0 & 0 \\
\hline 21 & 60900112049 & Herwin Akbar & 2 & 2 & 2 & 6 & 40 \\
\hline 22 & 60900112050 & Nurul Fajrina Yusran & 3 & 2 & 3 & 8 & 53,33 \\
\hline \multicolumn{7}{l}{ Mean Scores } &
\end{tabular}

Note: F(Fluency)

A (Accuracy)
$C$ (Comprehension)

For few details, the output above showed us that the students speaking ability before action implementation was inadequate. The mean score of their grade always 40,60. The grade was accumulated from their score of fluency, accuracy, and their comprehension. In addition, the researcher found that the maximun score of this test was $\mathbf{8 0}$ acquired by one student only otherwise the minimun score was $\mathbf{0}$ acquired by two students because of not joining the test. Moreover, the standard deviation of this test was 17,68 . The score mentioned in the text told us that overall the students' accumulated scores were beyond the researcher's expectation in this study. The students fluency, accuracy, and comprehension were 2 at most and a very small number getting 3 even 4 . Overall, the learning output of this pre-cycle test dissappointed the researcher and it ought to recover in the few next meetings.

In the first cycle, the researcher saw a quite improvement of students' speaking output after implementing action in the two meetings of this cycle. Moreover, the students' speaking problems in fluency, accuracy, and comprehension were pressed and decreased for a little. Their speaking mean score of this first cycle post-test was higher than their pre-cycle test.

Comparing to the pre cycle test, the students' speaking achievement of this first cycle test was better than before. It was found from this test that the mean score 
of their accumulated scores was higher than before. It absolutely indicated that the students' achievement in this test was quite better than the test they did in the pre cycle test before. The mean score this case was 47,27 whereas the mean score of the pre-cycle test was quite less 40,60. Furthermore, the standar deviation of this test $(\mathbf{1 6 , 4 4 )}$ was lower than the standar deviation of prior test $(\mathbf{1 7 , 6 8 )}$. This case, the lower standard deviation of the students' grade the better their grades.

It was found on this test that total score of students' speaking fluency was higher than before, their accuracy was better than their previous output, and their comprehension became up in this test either. Those comparison stated that an improvement of this test growing up after having implemented action meetings. Despite of remaining the lowest similiar score (0) because one student did not join the test again and even the highest similiar score (80) to the pre cycle test.

Overall, the students could held their conversation better in this cycle than in the previous moments. Their fluency was less forced by the language problems, their accuracy or their pronounciation less influenced by their mother tongue, and they were easier comprehend their partners' information. That improvement happening because the researcher tried to force their students' speaking ability becoming better with giving them enough practice and creating impressed learning in the class. He much more prepared class for this cycle rather than in the previous meeting in the hope his students' speaking achievement could increase.

In the second cycle, the researcher kept implementing this method IOC as an action class process in the hope the students' achievement becomes much more better in this further cycle. In spite of getting higher score in the first cycle test but the score did not achieve the goal of this research mentioned in the previous chapter three. That is way, the researcher utilized continuing the method and preparing more complex class on this cycle. He implemented action in the first and the second meeting, then giving post-action test again in the third meeting as the last meeting of this cycle.

Their accumulated score (grade) increased steply from the pre cycle test up to the first cycle test, then it higly increased up in this second cycle post test. As the findings of this test, the mean score of students' grade was $\mathbf{6 5 , 4 5}$ whereas the standard deviation was $\mathbf{9 , 1 1}$. Their grade in the pre cycle test was $\mathbf{4 0 , 6 0}$ (poor) then raised a quite in the first cycle post test $(\mathbf{4 7 , 2 7 )}$, the grade further became up $(\mathbf{6 5 , 4 5})$ in the second cycle post test. Additionally, the mean score of students' grade in this test already achieved fairly good. What the students had achieved in this test was 
Syarif H.N., To Improve Students' Interpersonal Communication Skills By Means of Cooperative ...

inside the researcher's expectation even though the score did not became good or excellent significantly.

Moreover, the researcher found something different from the number of standard deviation in this test. The standar deviation came down from 16,44 (the first cycle) to 9,11 (the second cycle). That means a lower standard deviation indicated a better mean score. Thus, the researcher getting proud of their students beacuse his students could increase better their grade at all from the pre-cycle test up to the second cycle test.

Following this, the students getting score 4 and score 3 of this test are more than in the previous test and less getting score 2 again. As a matter of expectation, there was one student successly got score 5 on his comperehension. In addition, the maximun grade of this test was $\mathbf{8 6 , 6 7}$ gained by one students otherwise the minimun

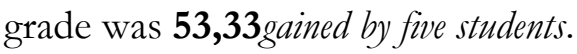

Further, the researcher presented the following different mean scores of students' grade through graphichs among the pre cycle test, the first cycle post test, and the second cycle post test as follows :

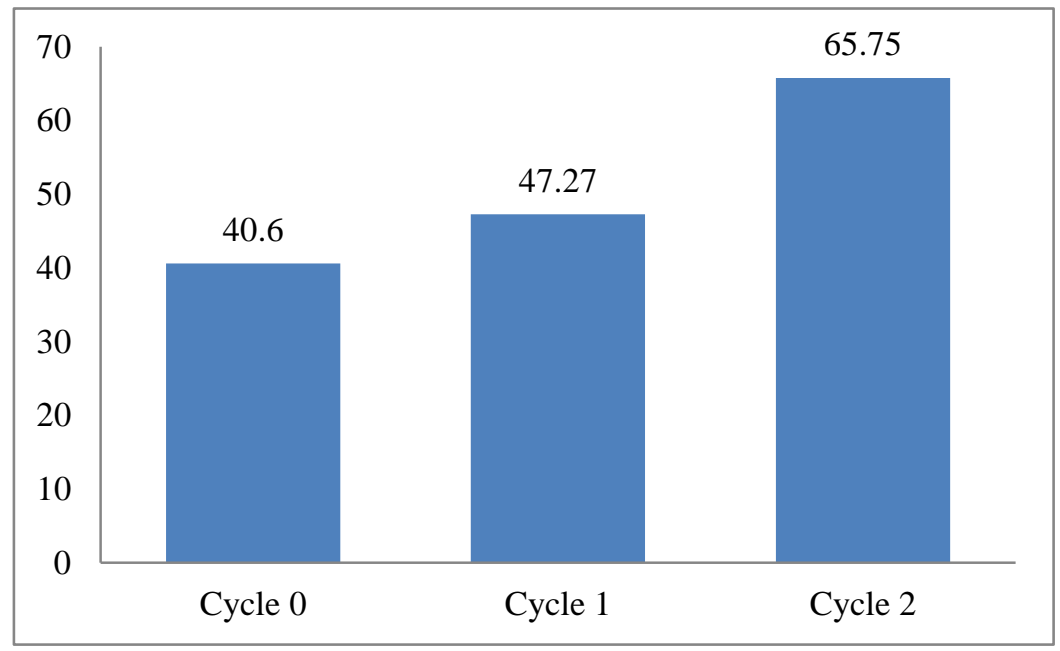

Mean Score Graphics of Students' Grades

This improvement of students' grade happened in each further cycle because the students showed their best with their partners speaking up in front of the class. They took more participation following the meetings in this cycle untill the test because none of the students missed the test again unlike in the pre cycle post-test and the first cycle post-test. The students on this test highly worked together with their partners comprehending their conversation. The way they spoke in front of the 
class were good already. They spoke with a little errors of accuracy, they spoke fluently enough, and they comprehended the ideas with enough understanding.

The researcher did not find serious problems any longer during implementing action on this second cycle especially in the moment giving them post cycle. The researcher saw the process of students doing the test with more active and more comprehensible. The students exchanged their ideas with high interest and attention to others. That all caused the process of the second cycle post test running well. As the result, their grade achieved good level likely the researcher's expectation of this research.

The researcher calculated the result of the students' score in the three moments of the test in order to know the standar deviation of each test. The standard deviation among them are presented as follows :

Fig 4. Mean Score and Standard Deviation Of Three Post-Tests

\begin{tabular}{|l|c|c|}
\hline \multicolumn{1}{|c|}{ Cycles } & Mean Score & Standar Deviation \\
\hline The Pre-Cycle & 40,60 & 17,68 \\
\hline The First Cycle & 47,27 & 16,44 \\
\hline The Second Cycle & 65,45 & 9,11 \\
\hline
\end{tabular}

\section{Reflections}

I did reflection in particular to respond what the collaborator had corrected in the way I taught in the classroom process. Here, I strengthen whet good I do and I otherwise reduced what not supposed to do in classroom teaching. In addition, the collaborator also offered me some critical and constructive suggestions which were very beneficial for the success of my research.

\section{F. SUGGESTION AND RECOMENDATION}

To sum up, there are a number of effective as well as required steps of implementing inside outside circle in order to improve the students' interpersonal conversation ability at the second semester students of PIBA of UIN Alauddin Makassar. Cooperative learning model ICO is quite effective to foster students' interpersonal conversation skill, of course by such certainly designed steps. Thereby, I confidently recommend these ways, the teachers are suggested to use cooperative learning to increase their students' participation in the learning process; the teachers, instructors, or tutor are highly encouraged to improve their students' output in conversation by the way of using inside outside circle. 
Syarif H.N., To Improve Students' Interpersonal Communication Skills By Means of Cooperative ...

\section{REFERENCES}

Agus N, Muhammad. 2011. Using Learning By Doing Method To Improve The Second Year Students' Speaking Skill at MAN 1 Bulukumba. A Thesis of PBI UIN Alauddin

Mustari. 2010. Improving Students' Speaking Ability of the second year level of MA As'adiyah Senior High School Callaccu Sengkang Through Cooperative Learning Group Investigation Approach. A Thesis of PBI UIN Alauddin.

Richard, J.C. 1990. Approaches and Methods in Language Learning, the second edition. New York. Cambridge University Press.

Holliday, A. 1994. Appropriate Methodology. Cambridge: Cambridge University Press.

Herrel, A. 1998. Strategies for teaching English language learners. New Jersey. Pearson Hall.

Long, H. Michael. 1987. Methodology in TESOL: A Book of Readings. U.S.A. Heinle Publishers.

Swaffar, J.,K. Arens, and M.Morgan.1982. Teacher classroom practices. Modern Language Journal.

Cambridge University Press.2000. Cambridge Dictionary of American English.UK: Cambridge University Press.

Zaini, Hisyam. 2008. Strategi Pembelajaran Aktif (Active Teaching Strategies). Yogyakarta. Pustaka Insan Madani.

Crystal, David. 2005. The Cambridge Encyclopedia of Language: Second Edition. USA: Cambridge University Press

Fromkin, V., Rodman, R., \&Hymas, N. 2003. An Introduction to Language: Seventh Edition.USA: Thomson Corporation.

Harris, D.R 1988. Testing English as A Second. New York: McGraw-Hill Book Company.

Hasan, Z. M; Sukaryana, 1.W. \&Waioedy.1997. Penelitiantindakan (Action Research).Jakarta: DeparemenPendidikandanKebudayaan.

Slavin, R.E. 1992. Cooperative Learning.USA: Allyn and Bacon.

Stringer, Ernie. 2004. Action Research in Education.Columbus: Pearson, Menvi Prentice Hall.

Wiraatmadja, Prof. Dr. Rochiati. 2006. MetodePenelitianTindakanKelas; UntukMeningkatkanKinerja Guru danDosen. Bandung: PT. RemajaRosdakarya 
Iqbal, Muhammad. 2007. Improving The Students' Tenses Understanding at The Second Year Students of MTs An-Nahdlah Makassar by Using Silent Way Method. Thesis of PBI UIN Alauddin

Johnson, D.W. \& Johnson, R.T. 1991.Learning Together and Alone: Cooperative, Competitive, and Individualistic Learning. Boston: Allyn and Bacon.

Johnson \& Johnson. 1994. Cooperative Learning in The Classroom. Virginia, Association for Supervision and Curriculum Development.

Lie, Anita. 2002. Cooperative Learning. Jakarta: Grasindo.

Mills, Geoffrey. 2003. Action Research: A Guide for the Teacher Researcher.New Jersey: Prentice Hall.

Murphy, R. \&Smalzer, W.R. 2002. Basic Grammar in Use.UK: Cambridge University Press.

Nurbaya, Siti. 2009. Students' Motivation in Learning English by Using Socio-Affective Learning Strategy trough Cooperative Learning at The Second Year Students of Madrasah AliyabMadaniAlauddinPao-PaoGowa. Thesis of PBI UIN Alauddin.

Person Education Limited. 2004. Longman Dictionary of American English.England: Longman.

Rusmiati. 2009. Teaching Procedural Texts Through Cooperative Learning Method to Improve The Students' Writing Ability at The Second Year of MTs AisyiyabSungguminasa. Thesis of PBI UIN Alauddin. 